\title{
Improving Switzerland's Image: Relations with Independent Mozambique
}

When Mozambique became independent in June 1975, Swiss-Mozambican relations were tense. Confidently looking forward to a bright future, FRELIMo's leadership criticised Switzerland's selective interpretation of neutrality during the independence wars and its cordial relations with the white minority regimes in South Africa and Rhodesia. The new government nationalised Swiss assets in Mozambique and numerous Swiss business people and missionaries left the country, together with many Portuguese and foreign citizens. Four years later, the situation had changed. Natural disasters, the departure of skilled workers, the loss of remittances from Mozambican mine workers in South Africa due to a change in the Rand mines' recruitment policies, and the ruling party's moves towards a planned economy drastically reduced Mozambique's economic output. The security situation had also deteriorated. In retaliation for FRELIMO's support of Rhodesian nationalist movements, the Rhodesian army started to attack targets in Mozambique. Its secret services were instrumental in the creation of the Mozambican National Resistance (MNR). While this movement did not represent a serious military challenge to the Mozambican government in the late 1970s, its guerrilla activities had a destabilising effect. In the 1980s, it became known under the name Resistência Nacional Moçambicana (Mozambican National Resistance, RENAMO) and its equipment and training were taken over by South Africa. ${ }^{1}$ Yet, by early 1979 , political relations between Switzerland and FRELIMO were cordial and the two governments even planned for a courtesy visit by the Mozambican president to Bern. In October 1979, the two governments signed a bilateral trade and economic cooperation agreement.

In the mid- to late 1970s, Mozambique was the only one of the four radical states in sub-Saharan Africa whose government developed a close bilateral relationship with Switzerland. This was mainly a result of the Swiss government's efforts to improve its image in the former Portuguese colonies and, at the same time, strengthen links with a newly decolonised Third World state. In Bern, Mozambique mattered for several reasons. First, there were Swiss

1 See Newitt, "Mozambique”. 
citizens living in this state whose interests the FPD had to protect during the political, economic, and social transformations of the first years of independence. Second, as one of the Frontline States committed to the struggle against white minority rule in Rhodesia and South Africa, the Mozambican government was an important actor in regional politics. Third, despite Rhodesian cross-border raids and the increasing activity of the MNR, Mozambique was relatively stable and peaceful, and thus offered opportunities for bilateral cooperation. Unlike Angola, Ethiopia, and Somalia, Mozambique was not the arena of a major conflict that influenced the shape of the Cold War. Consequently, neutrality considerations and East-West tensions weighed less on Swiss decision-making. In the context of growing North-South polarisation, most Western European governments and even the US State Department were eager to get on the Mozambican government's good side. In Bern, the officers tasked with handling relations with Mozambique at an administrative level treated it, for the most part, like any other developing state and paid little attention to its Soviet ties.

The FRELIMO government was, initially, more hesitant to develop its bilateral relations with Switzerland. After Mozambique's independence, the new rulers were welcomed by Third World states, supported by the Eastern bloc, and courted by most Western European governments. Establishing diplomatic relations with a state that had consistently kept its distance during the independence wars and refused to support national liberation was not a foreign policy priority for the new government. Growing economic and military difficulties towards the end of the 1970s changed this. Bern's willingness to focus its development cooperation policy on Mozambique and hopes of benefiting from close economic relations explain why the FRELIMO government responded to Swiss overtures.

Against the backdrop of the Cold War in Africa, regional conflict, and North-South tensions, the Swiss government's image improvement campaign in Mozambique between 1975 and 1979 focused on three aspects: the establishment of diplomatic relations, the creation of a bilateral aid relationship (that continues to the present day), and the protection of economic interests. Although these policy fields were interconnected, it is useful to consider them separately, as they involved different strategies and actors, both within the Swiss federal administration and in civil society. Nevertheless, the conclusion of the bilateral trade and economic cooperation agreement in late 1979 brings these various interests together. 


\section{A Lesson for the 'Capitalists'? Swiss Diplomacy's Difficulties in Establishing Diplomatic Relations}

While open war broke out between the Angolan liberation movements, FRELIMO's rise to power on 25 June 1975 was uncontested. The Swiss government recognised Mozambique on the same day. Intent on improving the country's image in Southern Africa and protecting the interests of Swiss business people and missionaries in Mozambique, the FPD subsequently sought to establish diplomatic relations. However, at that time, Swiss foreign policymakers were confronted with the consequences of their selective interpretation of neutrality during the independence war. ${ }^{2}$ FRELIMO was assertive and made a clear distinction between states that had supported its struggle and those that had not. Switzerland was clearly in the latter category. Unused to such confident behaviour from a newly decolonised state, most Western European governments and even the US State Department scrambled to get into FRELIMo's good books. The ambassadors of Sweden, Norway, Denmark, and Portugal were among the first to formally present their credentials to the Mozambican government a few days after independence, together with the representatives of selected African, Asian, and Eastern bloc states. ${ }^{3}$ However, those Western states that had established consulates during the colonial period were forced to close them down. FRELIMO ignored or rejected their repeated attempts to establish diplomatic relations. According to consul Bruno Stöckli, who had no official standing after the closure of the Swiss consulate, the Mozambican government wanted to "teach a lesson to the 'capitalists". 4

This antagonism also affected Swiss missionaries. In a public speech a month after Mozambique's independence, President Samora Machel attacked the Catholic Church and Swiss and US Protestant missions as well as their 'imperialist' countries of origin. Religious organisations were accused of being enemies of the people and all privately owned hospitals and schools were nationalised. This public hostility caused much consternation, although the DM's leadership realised that it was mainly intended to unify the country. In fact, the former IPM hospitals and schools continued to run smoothly

2 This section is derived in part from Sabina Widmer, "D'une "neutralité abstentionniste" à une solidarité instrumentalisée: L'établissement de relations diplomatiques entre la Suisse et le Mozambique", Relations internationales 163:3 (2015), pp. 81-94.

3 List attached to the letter from Bruno Stöckli, Swiss consul in Mozambique, to the DPA, "VR Mozambique. Bilaterale und multilaterale Beziehungen”, 29.08.1975, SFA E2001E-01\#1987/ $78 \# 4178^{*}$.

4 Letter from Bruno Stöckli to the DPA, "VR Mozambique. Beziehungen zur westlichen Welt", confidential, p. 2, SFA E2001E-o1\#1987/78\#4178*. 
and the Mozambican government even expressed its wish to collaborate with the DM in the healthcare sector. Nevertheless, due to the political and economic transformations in Mozambique, especially the nationalisations and continuing public criticism of churches, the Swiss missionary presence fell by almost two-thirds between mid-1974 and June 1976. Of the 16 people that remained, more than half signed work contracts with the Mozambican government. ${ }^{5}$

Since the Swiss parliament had decided, on 20 June 1975, to open embassies in Angola and Mozambique, FPD leaders decided not to push for the establishment of diplomatic relations with Mozambique before the expiry of the threemonths referendum period in late September. ${ }^{6}$ In hindsight, Bern's passive role over these months was a miscalculation. By the time Swiss diplomats in Dar es Salaam and New York took up the issue in mid-September, the UK and the US had formalised their links with FRELIMO. ${ }^{7}$ FRELIMO attached great importance to following the correct procedures for the establishment of diplomatic relations. Nevertheless, the Mozambican Foreign Minister, Joaquim Chissano, finally promised the Swiss Permanent Representative to the UN to make an exception and deal with this issue after his return from the UNGA in midOctober. ${ }^{8}$ This positive sign was all the more important as the FPD was facing domestic criticism of the way it had handled relations with Mozambique. A DM member claimed that the department had been discourteous to the two FRELIMO members that visited Bern in May 1975, and insisted that the choice of Swiss diplomats in Mozambique revealed a lack of judgment; both consul Bruno Stöckli and Paul Etienne Jaccaud—who was Swiss ambassador to Tan-

5 Circular letter by Marcel Vonnez, Swiss missionary in Mozambique, 28.07.1975, ADM, 3057G; minutes of the $119^{\text {th }}$ meeting of the DM's Council on 04.09.1975, no date, confidential, p. 5, ADM, folder Conseil 1973-1978; Albert Rotach, DM, memorandum, "Noté au 7e Colloque, 14 avril 76", 15.04.1976, ADM, 1851B, box 26o.

6 Letter from Jürg Andreas Iselin, deputy chief of DPA and chief of its African, Asian, Middle Eastern and Latin American Division, to the Swiss consulate in Lourenço Marques, 28.07.1975, confidential, SFA E2001E-o1\#1987/78\#4178*.

7 On 16 September 1975, it was announced that diplomatic relations between the UK and Mozambique were established as from 22 August. US-Mozambican relations were established on 23 September 1975: J. H. Lewen, British ambassador in Mozambique, report, "Mozambique: Annual Review for 1975. The Year of Independence", 02.01.1976, p. 7, TNA FCO $45 / 1898$.

8 Letter from Sigismond Marcuard, Ambassador at the Office of the Permanent Observer of Switzerland to the United Nations, to the DPA, "Etablissement des relations diplomatiques avec le Mozambique", 26.o9.1975, SFA E2001E-o1\#1987/78\#4178*; letter from Marcuard to the DPA, "Etablissement de relations diplomatiques avec la République populaire du Mozambique", 10.10.1975, ibid. 
zania and designated representative to Mozambique- had formerly acted as representatives to the Portuguese regime. ${ }^{9}$

On 4 November 1975, Western consulates in Lourenço Marques were informed that all personnel that had taken up their posts before independence had to leave the country within a week, on pain of expulsion. It soon transpired that only those states that had not yet established diplomatic relations with Mozambique were affected. ${ }^{10}$ To the leaders of the FPD, the expulsion of Stöckli was a radical change of attitude after the cordial talks in New York. The only foreign consul to have taken up his post during the transitional period, Stöckli was in a singular position. Although the severing of all links with the colonial period was a matter of principle for the Mozambican leadership, its foreign ministry relented after the FPD's Secretary General asked it to reconsider Stöckli's expulsion. The Mozambican authorities insisted, however, that Bern conform to the suggested manner of establishing diplomatic relations through a formal exchange of notes. ${ }^{11}$ Consequently, on 25 November 1975, Pierre Graber sent an official telegram to Joaquim Chissano to enquire about a date for the establishment of diplomatic relations. ${ }^{12}$ As the deadline given to foreign consulate personnel, 11 November 1975, was also the date of Angola's independence, the matter of a possible connection needs to be addressed. It is likely that the approach of Angolan independence spurred the Mozambican authorities to cut all ties with the colonial period. Although this could give rise to speculation that they attempted to put pressure on Western governments to recognise the allied MPLA government in Angola, there is no proof of such activity.

Jean-Paul A. Widmer, DM, memorandum, "Note concernant les contacts entre le Département Politique Fédéral et les envoyés du gouvernement de la République Populaire du Mozambique, précédemment Frelimo", 30.o9.1975, SFA E2001E-o1\#1987/78\#4651.

The personnel of the US, UK, Italian, and Dutch diplomatic representations were exempt from expulsion: Telegram from [?] Arenales, US consulate in Mozambique, to the Secretary of State, 04.11.1975, NARA, RG 59, AAD, CFPF, Electronic Telegrams 1975, 1975LOURENo1176; see also telegram from Arenales to the Secretary of State, 05.11.1975, NARA, RG 59, AAD, CFPF, Electronic Telegrams 1975, 1975LOURENo1180.

11 Telegram no 285 from Alfred Glesti, AD, to the Office of the Permanent Observer of Switzerland to the United Nations, 04.11.1975, SFA E20o1E-01\#1987/78\#4178*; telegram no 307 from Sigismond Marcuard to the FPD, 04.11.1975, ibid; Telegram from Ernesto Thalmann, Secretary-General of the FPD, to the Secretary-General of the Mozambican Foreign Ministry, 06.11.1975, SFA E2001E-o1\#1987/78\#4178*; letter from the Mozambican Foreign Ministry to Thalmann, 17.11.1975, ibid.; telegram from the Secretary-General of the Mozambican Foreign Ministry to Thalmann, 20.11.1975, ibid. 
As international outrage against the South African intervention in the Angolan War increased and the MPLA gained ground militarily, the Swiss authorities continued their increasingly solitary efforts to formalise their links with Mozambique. In early February 1976, the FRG, which had granted a large loan to Mozambique, established diplomatic relations with the FRELIMO government. ${ }^{13}$ France achieved the breakthrough on 19 February, two days after leading the Western European states' recognition of the People's Republic of Angola (PRA). Bruno Stöckli was convinced that it was the early recognition of Angola that made the Mozambican authorities overlook France's heavily criticised colonial policy. ${ }^{14}$ In late February 1976, Switzerland was the last state with a consulate in the Mozambican capital —now renamed Maputo—-that had not yet established diplomatic relations with Mozambique. As the Angolan War wound down and the PRA gained international, including Swiss, recognition, the Swiss government finally received encouraging signs from its Mozambican counterpart. On 12 April 1976, the two states established diplomatic relations. ${ }^{15}$ As the Mozambican government did not react to Bern's request for accreditation of Paul Jaccaud and the Swiss embassy in Tanzania was already responsible for Swiss relations with several other African states, the AD decided to accredit the Swiss ambassador to Ethiopia, Olivier Exchaquet, to both Mozambique and Angola. It can be assumed that this decision, which was certainly not made for reasons of geographical proximity, was partly based on the three states' similar ideological orientation. ${ }^{16}$

Why did it take the Swiss authorities more than nine months to establish diplomatic relations with Mozambique? Did Frelimo deliberately snub Switzerland? In the absence of Mozambican sources, it is impossible to answer these questions conclusively. FPD officials struggled to understand the Mozambican leaders' assertive attitude. In a speech to Swiss ambassadors posted to sub-Saharan Africa in September 1976, Jürg Andreas Iselin of the DPA placed the fault squarely with the Mozambican authorities. According to him, their

13 Telegram from Johnnie Carson, chargé d'affaires a.i. of the US embassy in Mozambique, to the Secretary of State, 04.02.1976, NARA, RG 59, AAD, CFPF, Electronic Telegrams 1976, 1976LOURENoo112, see also the telegram from Carson to the Secretary of State, 15.01.1976, NARA, RG 59, AAD, CF PF, Electronic Telegrams 1976, 1976LOURENooo44. from Bruno Stöckli to the FPD, 19.02.1976, SFA E2OO1E-o1\#1988/16\#46o2**. Telegram no 13 from Bruno Stöckli to the FPD, 08.o3.1976, SFA E20o1E-o1\#1988/16\#46o2*; telegram from Pierre Graber to Joaquim Chissano, 12.04.1976, ibid.

16 Excerpt of the minutes of the Federal Council's meeting on 25 May 1976, pp. 3-4, SFA E2004B\#199o/219\#373; letter from Fritz Bohnert, Swiss ambassador in Ethiopia, to the AD, "Addis Abeba: Parallelakkreditionen", 24.10.1980, SFA E2O24A\#199o/221\#68*. 
formalism, lack of administrative experience, rudimentary bureaucracy, communication deficits, and personal grudges were responsible for the delays. ${ }^{17}$ Consul Bruno Stöckli was convinced that Marcelino dos Santos had personally blocked Switzerland's file at the Foreign Ministry. ${ }^{18}$ More likely than sinister machinations by the Mozambican Vice President is the explanation advanced by an Undersecretary of the South African Foreign Ministry in February 1976; the establishment of diplomatic relations with Switzerland was "hardly at the top of the collective leadership's priority list".19

The severely short-staffed Mozambican administration faced major political, economic, and social challenges after independence. At the same time, FRELIMO was in a position of power and could afford to be selective in its foreign relations. For the Mozambican authorities, Switzerland was a member of the capitalist camp. Its government's insistence on a selective interpretation of neutrality must have rung hollow to FRELIMO's leaders during the independence war. In the context of the racial conflicts in Southern Africa, neutrality per se was no recommendation in the eyes of African nationalists. Neutral Sweden's support for national liberation granted it a place among FRELIMO's allies, while Austria formalised its links with FRELIMO even later than Switzerland, in mid-October. This delay seems to have been due mainly to Vienna's lack of interest in forcing the issue. ${ }^{20}$ If the Mozambican leaders intended to show their displeasure with Portugal's former allies, this carried less political risks in the case of a small state with limited geopolitical influence.

2

\section{"Considerable Political Interest in Showing Swiss 'Goodwill”: The Beginning of a Development Cooperation Partnership}

Ever since the late 196os, the possibility of granting aid to the African populations in the Portuguese colonies as a means of improving the image of Switzerland's neutrality had been discussed within the Swiss federal administration. gen der Schweiz zum Südlichen Afrika", p. 7, appendix no 20 of the minutes of the Annual Conference of Ambassadors, 01.09.1976-03.09.1976, no date, SFA E2O1O-O1A\#199o/5\#9*.

18 Telegram no 13 from Bruno Stöckli to the FPD, o8.o3.1976, SFA E2001E-o1\#1988/16\#46o2*.

19 Cited in the letter from Théodore Curchod, Swiss ambassador in South Africa, to the Secretary-General of the FPD, "Mosambik, Rhodesien aus der Sicht Pretorias", pp. 2-3, 10.02.1976, SFA E2OO1E-o1\#1988/16\#4616.

20 Airgram from Wiley Thomas Buchanan Jr., US ambassador in Austria, to the Department of State, "Austria and Mozambique Establish Diplomatic Relations", 19.10.1976, NARA, RG 59, P-Reel Printouts 1976, $\mathrm{P}_{7} 6 \mathrm{o164}_{4}-2241$, box 164D. 
Although the STC was not usually active in dependent territories, it had granted financial support to DM missionaries in Mozambique. The end of the anticolonial war and Mozambique's approaching independence removed the main obstacle to Swiss development aid in this country. While planning its future bilateral relations with Portugal's former colonies in early 1975, the DPA underlined the "considerable political interest in showing Swiss 'goodwill" by granting aid to these territories. ${ }^{21}$ Independent Mozambique, a champion of national liberation whose government would play an important role in the negotiations for an end to minority rule in Rhodesia, was an ideal candidate to implement this strategy. Consequently, the FPD embarked on a policy that would turn this country into a key state for Swiss development cooperation up to the present day. ${ }^{22}$

Switzerland's image problems in Southern Africa ensured that the attention of the FPD services responsible for foreign aid was already on Mozambique before the new state achieved independence. In September 1975, the STC's Eastern Africa Group, whose responsibility included the countries in Southern Africa, decided to extend its activities to two further countries in addition to its four selected key states of Rwanda, Kenya, Madagascar, and Tanzania. Its recent independence and its leaders' clear development priorities meant that Mozambique was the only state singled out for future development cooperation. ${ }^{23}$ The growing intensity of the liberation wars in Southern Africa after the end of the Angolan War in early 1976 increased the FPD's political interest in strengthening its humanitarian role in the region. As most other states in the area were either judged politically unstable or were under white minority rule and thus not eligible to host STC projects, Mozambique and Lesotho were the only candidates for more substantial Swiss aid. ${ }^{24}$ Subsequently, the STC

21 Note from Alfred Reinhard Hohl, DPA, to the stc, "Guinea-Bissau. Angola. Mozambique", 17.02.1975, SFA E2OO5A\#1985/101\#547*.

22 STC, Trade Division (eds.), Schweiz-Mozambique. 30 Jahre bilaterale Zusammenarbeit von 1979 bis 2009, Bern: STC, 2009. See also Federal Council, press release, "Switzerland and Mozambique discuss peace and sign an international cooperation agreement", 28.02.2018, https://www.admin.ch/gov/en/start/documentation/media-releases.msg-id-69945.html (13 January 2021).

23 Rudolf Dannecker, head of the sTc's Eastern Africa Section, work programme, "TechnischeZusammenarbeit Ostafrikagruppe. Programmund Richtlinien für die technische Hilfe in der Ostafrikagruppe, 1975-1979", September 1975, pp. 3-4, SFA E2005A\#1985/101\#225*.

24 Note from Thomas Raeber, deputy head of the STC, to the Political Secretariat, "Die schweizerische technische Zusammenarbeit und das südliche Afrika. Ihre Anfrage vom 11. Mai 1976", 04.06.1976, SFA E2005A\#1991/16\#541*. 
examined the possibility of contributing to an agricultural project organised by the FAO, with a view to gaining experience in an unfamiliar country. ${ }^{25}$

In parallel to this slow start to a bilateral development cooperation relationship, the Dio continued to grant humanitarian aid to Mozambique through the intermediary of Swiss and international charities. Donations mounted from CHF 275, OOO in 1976 to CHF 880,000 in 1977, but dropped to CHF 370,000 in $1978 .{ }^{26}$ Part of this aid was destined for Rhodesian refugees. After Mozambique's independence, the liberation movement Zimbabwe African National Union (ZANU), which was supported by the FRELIMO government, used the new state as a base for its attacks against the Smith regime. The ensuing repression by the Rhodesian authorities caused more than 250,00o black Zimbabweans to flee to neighbouring countries until the Lancaster House peace agreement of late 1979 put an end to the white minority regime in Rhodesia. Overall, 160 , ooo of these refugees made their way to Mozambique, which burdened the young state's economy. ${ }^{27}$

Switzerland's humanitarian and development aid was instrumental to improving bilateral relations with FRELIMO from mid-1976 onwards. Before leaving Switzerland to take charge of the newly opened Swiss embassy in Maputo in early 1977, Claude-Louis Piachaud was asked to keep the DIO informed of all possibilities for granting further aid to Mozambique. The correspondence between the DIO and Piachaud shows a preoccupation with making Swiss aid as visible as possible, which testifies to the Swiss authorities' intent of providing FRELIMO with tangible proof of Switzerland's goodwill. This strategy undoubtedly paid off: when Piachaud enquired about Mozambique's need for international aid in February 1977, he was cordially received by Marcelino dos Santos, whose hostility towards Switzerland had been frequently cited as a reason for the FPD's difficulties in establishing diplomatic relations with Mozambique. ${ }^{28}$ As the young state was facing increasing economic and

25 Letter from Rudolf Dannecker to the Swiss embassy in Ethiopia, "Coopération technique avec le Mozambique”, o3.o9.1976, p. 1, SFA E2001E-o1\#1991/17_Bd.985, B.55.40; letter from Dannecker to the Swiss embassy in Ethiopia, "Projet d'aide associée avec la FAO au Mozambique”, 12.08.1976, SFA E2005A\#1991/16\#1029*.

26 Note from LV to Philippe de Rham, stc, "Aide humanitaire en faveur du Mozambique", 02.05.1979, SFA E2O25A\#1991/168\#1259*.

27 Nathaniel Kinsey Powell, "The UNHCR and Zimbabwean Refugees in Mozambique, 19751980", Refugee Survey Quarterly 32:4 (2013), pp. 41-65, pp. 42-45.

28 See notably the letter from Claude-Louis Piachaud to the DIO, "Section de secours en cas de catastrophe à l'étranger", 19.02.1977, SFA E2001E-o1\#1991/17_Bd.985, B.55.4O; letter from Piachaud to the DIO, "Section des oeuvres d'entraide internationale", 22.03.1977, SFA E2003A\#199o/3/633*; letter from Piachaud to the DIO, "Aide au Mozambique du 
political difficulties, due notably to natural calamities and the intensification of the conflict in Rhodesia, it was in great need of foreign aid. FRELIMO could therefore no longer afford to differentiate between friends and foes from colonial times.

Private Swiss actors played a singular role in bilateral development cooperation. The FRELIMO government adopted a unique policy of recruiting and hiring independent foreign experts. These experts, numbering about 2,00o in the early 1980s, were remunerated by the Mozambican authorities and occupied important positions in FRELIMO's administration. ${ }^{29}$ Although their number varied, about 25 Swiss volunteers worked in Mozambique in the late 197os. Most of them belonged to one of two categories: first, some former members of the DM continued their humanitarian work after the nationalisation of missionary hospitals and schools as employees of the Mozambican state. Despite FRELIMO's public hostility towards religious organisations, the DM continued to collaborate closely with the IPM and to grant financial and material support to the young state. Its leaders no longer sent medical or teaching staff to independent Mozambique. Instead, they encouraged volunteers to contact the Mozambican authorities directly. Continuing close interest in the fate of the young republic was also fuelled by personal contact with the president and the ministers of health and development. The DM supported the Swiss authorities' plans to start development cooperation with independent Mozambique and continued to be a valued source of information for Swiss diplomats. ${ }^{30}$ Second, a number of people, usually young and left-wing, left Switzerland to help build a postcolonial socialist state. ${ }^{31}$

The attitudes of FPD officials towards these private volunteers were ambivalent, as shown by internal discussions of whether the Swiss government should

Gouvernement suisse et de la Croix-Rouge Suisse après les inondations de janvier 1977", 12.07.1977, SFA E2001E-o1\#1991/17_Bd.985, B.55.40.

29 Georges Capt, sTC, report, "Rapport de mission au Mozambique février 1981", 25.03.1981, p. 2, SFA E2O25A\#1991/168\#1261*.

30 Letter from Georges Guinand, President of the Council of the DM, and Georges Morier-Genoud, Secretary General of the DM, to Jürg Andreas Iselin, 07.09.1977, SFA E2001E-o1\#1991/17_Bd. 984; B.15.21; letter from Rudolf Dannecker to the Council of the DM, 25.09.1977, SFA E2005A\#1991/16\#1029*; minutes of the 140th meeting of the DM's Council on 10.09.1977, no date, confidential, p. 9, ADM, folder Conseil 1973-1978; minutes of the 151th meeting of the DM's Council on 21.10.1978, no date, confidential, pp. 6-7, ibid. On FRELIMo's attitude towards churches after Mozambique's independence, see Eric Morier-Genoud, Of God and Caesar. The Relation Between Christian Churches and the State in Post-Colonial Mozambique, 1974-1981, Lausanne: Le Fait Missionnaire, 1996.

$31 \quad$ Letter from Olivier Exchaquet, Swiss ambassador in Ethiopia, to the AD, "Opportunité d'ouvrirunerepresentation permanenteà Maputo”, o2.08.1976, SFA E2004B\#199o/219\#373*. 
top up their salaries. In August 1976, Olivier Exchaquet, the Swiss ambassador accredited to Mozambique, insisted that these "young people who came to aid Mozambique out of idealism (frequently Marxist)" were nevertheless "good patriots" and suggested that the STC might grant them some financial support. ${ }^{32}$ His successor, Fritz Bohnert, was less open-minded. Fearing for the image of Switzerland's neutrality, he pointed out the political risk of paying volunteers over whose recruitment and activities Bern had no control. ${ }^{33} \mathrm{He}$ must have felt vindicated in late October 1979, when some private Swiss development workers made a small gift of $\mathrm{CHF} 4,300$ to the Mozambican government to aid its defence capacities against Rhodesian attacks. The STC, which was in favour of topping up their salaries, subsequently felt compelled to insist that these volunteers had no official mission from the Swiss authorities and did excellent work for a small Mozambican salary. ${ }^{34}$ Although Swiss policymakers frequently noted that the private development workers improved Switzerland's image in Mozambique, the latter's importance should not be overestimated. Their number was insignificant compared to the 25 o Swedish nationals working for FRELIMO in late 1979, whose salaries were paid from a special Swedish grant to the Mozambican government. ${ }^{35}$

The STC continued its plans to start a long-term cooperation partnership with Mozambique, despite the increasing military insecurity in the state. After exploratory talks in February 1978, an initial agreement for a small Swiss aid programme was reached three months later. Shortly afterwards, foreign development workers were explicitly targeted by anti-FRELIMo forces. In June 1978, a Belgian couple working for the FAO were assassinated in the province of Manica and in the following month, a bomb exploded in a café in Maputo that was frequented by Portuguese development workers. ${ }^{36}$ These events

$32 \quad$ Ibid., p. 4 .

33 Letter from Fritz Bohnert to the DPA, the STC, and the Trade Division, "Mosambik: bilaterale Beziehungen - Handelsvertrag - ERG - Projekte TZ”, pp. 6-8, SFA E2Oo1E-o1\#1991/17_ Bd. 984 ; B.15.21.

34 Henri-Philippe Cart, head of the stc's Eastern Africa Section, memorandum, "Don de coopérants suisses à la République du Mozambique”, 22.10.1979, SFA SFA E20o1E-o1\#1991/ 17_Bd.985, B.55.4O; see also the letter from Claude-Louis Piachaud to the FPD's Information and Press Service, "Don de coopérants suisses à la RPM", 04.10.1979, SFA E2025A\#1991/ $168{ }_{1259 *}$.

35 Letter from Fritz Bohnert to the stc, “Die 'spontanten Kooperanten' in Mosambik. Topping-up. Politische Funktionen”, 29.10.1979, SFA E2O25A\#1991/168\#1259*.

36 Jean-Maurice Délèze, report, "Mission au Mozambique. 23-26 février 1978", March 1978, SFA E2005A\#1991/16\#1030*; letter from Claude-Louis Piachaud to the Political Secretariat, “'Terrorisme' au Mozambique", 28.07.1978, SFA E2010-o1A\#199o/5\#97*. 
do not seem to have had any effect on the STC's cooperation policy. In January 1979, the service approved the Eastern Africa Group's proposal for an aid programme for Mozambique amounting to $\mathrm{CHF} 4$ million. It included projects in the fields of water supply, health centres, rural development, food safety, the topping up of the salaries of private development workers, and land surveying, mostly in the north-eastern province of Cabo Delgado. ${ }^{37}$ The proposal was curiously silent about the political situation in Mozambique and made no reference to the activities of the MNR at all. The strong and enduring political will to make a positive humanitarian contribution in Southern Africa explained why the STC was dedicated to following a course set in 1975, when the intensifying civil war in Mozambique could not have been predicted. An element of international competition probably also played a role. In addition to unquantifiable Eastern bloc aid, Mozambique had received Western and UN financial and technical aid amounting to $\$ 95$ million in 1977. Sweden, Norway, Finland, Denmark, and Iceland had concluded a global agreement for aid amounting to $\$ 50$ million over three years. ${ }^{38}$ For these reasons, the sTC downplayed the risks associated with a long-term engagement in a state suffering from considerable civil unrest. At least in the decision to concentrate on the comparatively safe regions of Maputo and Cabo Delgado, the service took the military situation into account. ${ }^{39}$

With the launching of an STC aid programme in early 1979, development cooperation took off. The Southern African state was about to become the fifth key country for Swiss development aid. ${ }^{40}$ In the 198 os, the sTC continued its activities despite the escalation of the war between the government and RENAMO. Due to this long-term engagement in Mozambique, the Swiss authorities were able to play an important role in the peace process between FRELIMO and RENAMO in the early 199os, notably with regard to the demobilisation and reintegration of former soldiers. ${ }^{41}$

37 Rudolf Dannecker, proposal to the head of the STC, "Programme d'appui à l'effort de développement Mozambicain”, 16.01.1979, SFA E2200.70\#1993/404\#8*. See also telegram no 18 from [?] Voegele, FPD, to the Swiss embassy in Madagascar, 31.01.1979, SFA E2025A\#1991/168\#1259*.

38 Jean-Maurice Délèze, Philippe de Rham, "Mission d'identification de projets au Mozambique", October 1978, p. 5, attached to the note from Délèze to the STC, "Rapport de mission au Mozambique", 18.02.1978, SFA E2005A\#1991/16\#1030*.

39 STC, Trade Division, Schweiz-Mozambique, p. 22.

40 Henri-Philippe Cart, "Programme de coopération au développement 1980 de la Section Afrique orientale", February 1980, p. 1, SFA E2O25A\#1991/168\#670*.

41 STC, Trade Division, Schweiz-Mozambique, pp. 43-47. 


\section{"Healthy Obstinacy Pays Off": Challenges of Economic Decolonisation}

Mozambique's independence profoundly influenced Swiss trade with and investments in this territory. Insecurity about the colony's future after the Carnation Revolution and later the coming to power of an African government unsettled European business people and caused many colonists to leave the country between 1974 and 1976 . This had a disruptive impact on the economic development of the newly independent state. After the departure of the Portuguese colonial authorities, the FRELIMO government took over banks, statecontrolled companies, and ports formerly held by the colonial power. Swiss business people had to deal with new African leaders who were intent on breaking the links with the colonial economy and nationalising foreign property. ${ }^{42}$ As FRELImo consolidated its power in the second half of the 197os, economic actors had to find their place in the increasingly state-controlled economy. However, the changes introduced after Mozambique's independence also presented new opportunities, particularly for Switzerland's export industry. For the pharmaceuticals company Ciba-Geigy, for example, its good sales in Mozambique were, in early 1978, "proof that a healthy obstinacy pays off, especially during times of crisis". ${ }^{43}$ As the Swiss government and firms faced similar challenges in Mozambique and Angola, they often discussed the situation in the two former colonies interchangeably and adopted common strategies. Consequently, there is some overlap here with the next chapter.

The Carnation Revolution interrupted the general upwards trend in Switzerland's commercial exchanges with Mozambique. On average, they were on a lower level during the second half of the 1970s than they had been in the years before 1974, although Swiss exports picked up towards the end of the decade. In the late 1970s, Mozambique and Angola remained interesting export markets for Swiss machines and pharmaceutical companies. Ciba-Geigy, в вС, and Bühler were active in both countries, while Sulzer and Saurer equipped textile factories in Mozambique. ${ }^{44}$

42 Letter from Bruno Stöckli to the FPD's Financial and Economic Service and the Trade Division, "Mozambique. Portugiesisch/mozambikanische Zusammenarbeit", 17.04.1975, SFA E20o1E-o1\#1987/78\#4651; M. Anne Pitcher, Transforming Mozambique. The Politics of Privatization, 1975-2000, Cambridge: Cambridge University Press, 2002, p. 42. Ciba-Geigy SA, Rapport de gestion de CIBA-GEIGY SA 1977, Basel: Schwabe, [1978], p. 25.

44 Note from Hermann Jossen, DPA, to the designated Swiss ambassador in Angola, "ANG O LA. Schweizerkolonie”, 01.10.1976, SFA E2004B\#1990/219\#344*; letter from Giovanni Enrico Bucher, Swiss ambassador in Portugal, to the DPA, "Quelques renseignements sur la situation en Angola", 10.11.1976, SFA E2001E-o1\#1988/16\#1920*; Claude Louis Piachaud, chargé 
The Mozambican government's takeover of shares in the Cabora Bassa dam had little effect on ввС, which had been heavily criticised by African governments and Swiss solidarity movements during the independence war for the deliveries it had made to its German subsidiary. At a board meeting in November 1975, a few months after Mozambique's independence, it was reported that construction of the dam continued without disruption, "because FRELIMO is obviously interested in selling electricity." ${ }^{25}$ During the economic crisis of the mid-197os, Third World markets were important for Switzerland's export industry. In February 1976, ввС delegates observed at a board meeting that the growth of the group's business with African and Asian states had compensated for the lack of orders from its traditional markets caused by the recession in Europe and the strong Swiss franc. They agreed, however, that this boom was unlikely to continue, as the new markets already showed signs of saturation and the collaboration with state-trading countries presented further challenges ${ }^{46}$ Despite additional administrative burdens, the big Swiss export firms and multinational groups that were well-established on the Angolan and Mozambican markets were content with their affairs in these states in the late 1970 and qualified their collaboration with the state-controlled import organisations as satisfactory. ${ }^{47}$

These companies were little inconvenienced by the fact that the Swiss government no longer granted ERG covers once the risks associated with deliveries to Portuguese Africa became Mozambican and Angolan. The continuing instability and the difficult economic situation following the two states' independence in 1975 meant that Bern considered these risks too high to cover. The lack of a state guarantee was particularly disadvantageous for smaller firms. Whereas bigger companies like Sulzer, Saurer, and Ciba-Geigy obtained

d'affaires of the Swiss embassy in Maputo, memorandum, "Intérêts suisses. Représentations, firmes d'exportation", 17.04.1979, SFA E2001E-o1\#1991/17_Bd.984, B.15.50.4. For the development of Swiss trade with Mozambique, see chapter 1.

45 Cited in Dietrich, ввс Baden, minutes of the meeting of the Board of Directors on 18 November 1975 in Baden, no date, p. 19, НААвв, folder 253689, file 605626. See also

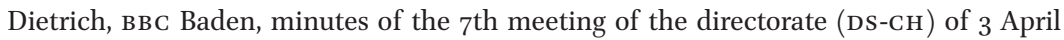
1975, 07.04.1975, p. 2, НAABB; Dietrich, minutes of the $6^{\text {th }}$ meeting of the directorate (DSCH), 20 March 1975, no date, p. 5, НАAв B.

46 Dietrich, ввс Baden, minutes of the meeting of the Board of Directors on 23 February 1976 in Baden, no date, pp. 15-16, HAABB, folder 253689, file 6o5626.

47 Cited in Hans Freiburghaus, chargé d'affaires of the Swiss embassy in Luanda, report, "Schlussbericht Schweizerische Botschaft Luanda", 25.10.1979, p. 3, SFA E2001E-01\#1991/17_ Bd.610, B.15.21; note from Jean Zwahlen, head of the FPD's Financial and Economic Service, to the DPA, "Visite du Président Machel en Suisse", 27.04.1979, SFA E20o1E-o1\#1991/17_ Bd.984, B.15.21. 
credit letters from banks. ${ }^{48}$ Switzerland's restrictive ERG policy was not only criticised by representatives of the African governments but also by Swiss export firms and banks, who pointed out that Angola and Mozambique had reliably honoured their financial obligations. In the case of Mozambique, this pressure had some effect. By 1979, ERG covers were again granted for shortterm contracts. ${ }^{49}$

After independence, Swiss banks collaborated closely with the Mozambican national bank, although it is difficult to obtain detailed information on this. In August 1978, a UBS delegation travelled to Maputo. This visit was probably linked to a revolving loan of CHF 20 million that UBS seems to have granted to the Mozambican government in the late 197os. Consequently, in October 1979, the Vice Director of the Mozambican national bank told the Swiss ambassador to Mozambique: "Switzerland is our best financial centre."50

Decolonisation and the takeover by Marxist-inspired FRELIMo had a negative impact on Swiss traders and business people established in Mozambique. Within a few years after the Carnation Revolution, most Swiss investments were under state control. Barring a number of smaller Swiss-owned trading firms and properties, the most significant case was that of the Companhia de Boror, the biggest copra producer in the country, which was nationalised in

48 Letter from Claude Louis Piachaud to the Trade Division, "Garantie contre les risques à l'exportation - Mozambique", 04.03.1977, SFA E7110\#1988/12\#1481*. See also the letter from Ernst Henri Léchot, responsible for relations with Portugal within the Trade Division, to the Swiss embassy in Maputo, "Mozambique: Garantie contre les risques à l'exportation", 16.03.1977, ibid.; note from Hermann Hofer, Vice-Director of the Trade Division and president of the commission for the ERG, to Léchot, "Exportrisikogarantie GA 4.39 Angola/ввс", 20.08.1974, SFA E7110\#1985/97\#1468*, and the attached memorandum, "Exportrisikogarantie", no author, 16.08.1974; letter from Léchot to the office for the ERG, "Portugal - ERG GA 4.39 Angola/BBC", 4.10.1974, SFA E7110\#1985/97\#1468*.

49 Letter from Ernst Henri Léchot to the Swiss embassies in Ethiopia and Mozambique, "Mozambique: Garantie contre les risques à l'exportation", 01.06.1979, SFA E2001E-o1\#1991/17_987, C.41.111.o, and attached notes; letter from Léchot to the Swiss embassy in Mozambique, "Mozambique: Garantie contre les risques à l'exportation", 21.06.1979, SFA E7114A\#1990/6o\#1533*.

50 Cited in Claude-Louis Piachaud, minutes, "Procès-verbal des principaux points de l'entretien entre Monsieur l'Ambassadeur Bohnert et le Vice-Gouverneur de la Banque du Mozambique, Prakash Ratilal, le 22 octobre 1979, au sujet plus particulièrement de la CCA ANGOCHE (AGAVA ZUG)", 22.10.1979, p. 1, attached to the letter from Piachaud to the Trade Division, "Mozambique: CCA ANGOCHE et développement des relations commerciales", 23.10.1979, SFA E7115A\#199o/6o\#1537*. See also the letter from Piachaud to the Financial and Economic Service of the FPD, "Délégation UBS au Mozambique", 25.08.1978, SFA E2001E-o1\#1991/17_987, C.41.111.o; Piachaud, report, "Mozambique - Rapport de synthèse", o3.10.1980, p. 7, SFA E7115A\#1990/142\#1585*. 
May 1976. The loss was put at CHF 65.5 million, $70 \%$ of which concerned Swiss investments. ${ }^{51}$ This nationalisation without compensation was justified on the grounds of economic sabotage; before leaving Mozambique, the company's managers had smuggled money and copra out of the country, sabotaged equipment, and failed to pay employees. ${ }^{52}$ The other major Swiss plantation, CCA, valued at CHF 27 million in 1974, was able to continue operations after Mozambique's independence. Its productivity suffered due to problems recruiting qualified personnel and workers, scarcity of material and spare parts, and difficulties obtaining permits. Losses were increasingly heavy. In August 1981, the Swiss investors decided to withdraw and hand the company over to local investors. ${ }^{53}$

In attempting to obtain compensation for nationalised Swiss assets, the DPA faced challenges similar to those it faced in Ethiopia, as nationalisations occurred before guidelines for compensation were issued. In Mozambique, the situation was compounded by the fact that Switzerland did not formalise its relations with the new rulers until spring 1976 . From June 1975 until early 1977 there was no functioning Swiss consulate in Maputo that might have acted as an intermediary. Therefore in June 1976, FPD leaders sent a note to the Mozambican foreign ministry, asking for more information about the nationalisation decrees issued in February 1975 and early $1976 .{ }^{54}$ Further interventions were not deemed useful. At the Third Frelimo Congress in February 1977, the Mozambican government officially adopted Marxism-Leninism. FRELIMO's economic interventions became more frequent and were now part of an ideological programme. A decree on compensation was enacted after the congress classified proprietors that had left Mozambique as enemies of the state. As such, they were not entitled to compensation. This was the case for most Swiss

$51 \quad$ Note from Hermann Jossen to the DPA and the DPIL, "Nationalisierungen in Angola und Mozambique - Geltendmachung schweizerischer Ansprüche”, 02.06.1976, SFA E2200.167\#1991/284\#51*; letter from Fritz Bohnert to the DPIL, "Mosambik: Ueberführung ausländischen Eigentums in die Verwaltung oder das Eigentum des Staates", 22.07.1977, SFA E2001E-o1\#1988/16\#4611*.

52 Pitcher, Transforming Mozambique, p. 39.

53 Claude Louis Piachaud, memorandum, "Données sur entreprises suisses au Mozambique", 17.04.1979, attached to the letter from Piachaud to the DPA, "Voyage Président du Mozambique en Suisse", 20.04.1979, SFA E7115A\#199o/60\#1542*; letter from Hanspeter Ammann, managing director of Agava Trading Ltd, to Georges Peyraud, chargé d'affaires of the Swiss embassy in Mozambique, 04.08.1981, attached to the letter from Arnold Hugentobler, DPA, to Agava Trading Ltd, "CCA Angoche", 10.08.1981, SFA E7115A\#1991/189\#1422*.

54 Note from Hermann Jossen to the DPA and the DPIL, "Nationalisierungen in Angola und Mozambique - Geltendmachung schweizerischer Ansprüche", 02.06.1976, SFA E2200.167\#1991/284\#51*. 
owners. ${ }^{55}$ The Swiss representative's frequent interventions were unsuccessful and by the early 1980s, there was still no sign that FRELIMO might be willing to start negotiating compensation. ${ }^{56}$

The example of the chemicals and pharmaceutical firm Ciba-Geigy, today Novartis, provides a fascinating inside view of how a Swiss multinational group adapted its strategy to the changing local context and managed to uphold and even increase its business volume in the first years after the independence of Mozambique and Angola. With a turnover of CHF 6,950 million in 1970, the Ciba-Geigy group headquartered in Basel was the second largest in Switzerland and would soon become one of the leading pharmaceutical companies worldwide. It was one of the main Swiss exporters to Angola and Mozambique after the fall of the Portuguese colonial empire, with chemicals and pharmaceuticals making up almost $6 \circ \%$ of Switzerland's exports to both states in the period $1977-1979 \cdot{ }^{57}$

In the 1950s and 196os, the export-oriented chemical and pharmaceutical firms Ciba and Geigy became increasingly multinational, creating sales organisations as well as production and research facilities on multiple continents. In 1970, the year in which the two companies merged, less than $5 \%$ of the group's total turnover was generated in Africa. ${ }^{58}$ As the bonds between the colonial powers and their African colonies had started to loosen in the late 1950s, Ciba had reorganised its sales policies in preparation for decolonisation. Until then, sales to African countries had been handled through offices in Paris, Lisbon, and Horsham (UK), and through headquarters in Basel. In view of the African continent's future importance, Ciba planned to open information and scientific offices in Leopoldville-renamed Kinshasa in 1966 - and Nairobi. It was hoped that these offices would handle sales with African states more effectively. ${ }^{59}$ Convinced of the continent's fast-growing potential, Ciba-Geigy's

55 Note from Hansjakob Kaufmann, deputy chief of the DPA's African, Asian, Middle Eastern and Latin American Division, to the DPIL, 29.07.1977, SFA E2001E-o1\#1988/16\#4611*; see also letter from Fritz Bohnert to the DPIL, "Mosambik: Ueberführung ausländischen Eigentums in die Verwaltung oder das Eigentum des Staates", 22.07.1977, ibid.; Pitcher, Transforming Mozambique, pp. 38-40.

56 Swiss embassy in Mozambique, memorandum, "Intérêts suisses", 06.10.1980, SFA E2200.307A\#1994/370\#19*.

57 Bernhard Degen, "Ciba", 30.03.2021, HLs Online; Christian Zeller, Globalisierungsstrategien - Der Weg von Novartis, Berlin: Springer, 2001, pp. 157-159; Swiss Directorate General of Customs, Jahresstatistik des Aussenhandels der Schweiz, 1967-1979.

$5^{8}$ Zeller, Globalisierungsstrategien, pp. 144-150, 158. See also Paul Erni, Mariage à la bâloise. Histoire de la fusion Ciba-Geigy, Zürich: NZz Verlag, 1979.

59 [?] Faraquier, sales department of country group III in Ciba's pharmaceuticals section, to the members of the Ph.G.A, "Zukünftige Organisation in den Gebieten Afrikas mit 
executive board charged its regional committee for Africa in late 1972 with developing a plan to improve the group's position in the recently decolonised African states. ${ }^{60}$ The training of local employees and their gradual promotion to senior management positions in order to limit the danger of expulsion and safeguard the group's position in Africa was an important part of Ciba-Geigy's strategy. In 1974, Ciba-Geigy's sales budget for Africa (excluding South Africa, Rhodesia, Egypt, Sudan, and Libya) reached CHF 200 million and its position on the continent was qualified as excellent. ${ }^{61}$ In early 1976 , the continent's share in total group sales was growing. Attendees at a meeting of the Regional Committee for Africa explained that this was due to the activities of branch offices in the different African countries. ${ }^{62}$

The Carnation Revolution initially had a negative impact on Ciba-Geigy's business in Angola and Mozambique. Sales figures in 1976 were significantly lower than they had been during the colonial period. In Angola, they dropped from CHF 10 million in the record year of 1974 to CHF 3.1 million in 1976, in Mozambique from CHF 5.3 million to CHF 3.5 million. ${ }^{63}$ Despite decreasing sales and the difficulties linked to regime changes and the war in Angola, the group maintained its branch offices in Luanda and Lourenço Marques. In November 1975, Ciba-Geigy's regional services prepared for possible nationalisations in Mozambique. They centralised their different offices in a new location, fearing that business might be impaired if the Boror company, on whose premises some of their offices had formerly been located, was nationalised. Thus, the group's leadership adopted a similar strategy to the one employed after the Ethiopian Revolution, when it chose to distance itself from its former

Negerbevölkerung (Afrique noire)", 19.08.1958, citation p. 2, Novartis archives, Ciba company archives, box KG K2, Kon 3 .

6o Minutes no 26/72 of the Ciba Geigy Group Executive Committee meeting on 14 November 1972, Novartis archives, Ciba-Geigy company archives, minutes: minutes of the Group Executive Committee, box KL.1.

$61 \quad$ Minutes of the meeting of the Ciba-Geigy Regional Committee for Africa on 21 January 1975, "Behandlung des Budgets 1975 Schwarzafrika", Novartis archives, Ciba-Geigy company archives, regional management, minutes of the regional committees, box RD 7-8, Afrika: RD 7.2.

62 H. Schwarb, minutes of the meeting of the Ciba-Geigy Regional Committee for Africa on 29 January 1976, pp. 3, 9, Novartis archives, Ciba-Geigy company archives, regional management, minutes of the regional committees, box RD 7-8, Afrika: RD 7.2.

63 H. Schwarb, report, "Bericht über meinen Aufenthalt in Angola / Mosambik vom 1.-10.3.77", 15.03.1977, Novartis archives, Ciba-Geigy company archives, minutes: various documents, box KL 1.o1, Aug 1976 - Dez 1979. 
agent that was threatened by nationalisation. This decision proved shrewd, as Boror was indeed nationalised in mid-1976. ${ }^{64}$

In September 1976, for the first time since the independence of Mozambique and Angola, a member of Ciba-Geigy's management travelled to the former Portuguese territories. H. Schwarb's detailed reports highlight the challenges the group faced during the consolidation of the rule of FRELIMO and the MPLA. The new governments' plans to control foreign trade, the possible nationalisation of further economic sectors, and, in Angola, the insecure military situation that reduced demand for agricultural and agrochemical products required strategic adjustments. Nevertheless, the author was optimistic about future business chances. He judged it important to maintain Ciba-Geigy's presence in order to keep a finger on the pulse and to help clients with bureaucratic problems. This would also contain the influence of the Eastern bloc: "I believe that the financial sacrifices necessary for $c G$ [Ciba-Geigy] are absolutely acceptable in order to make a modest contribution to the continuation of the economic presence of the West." 65 In Mozambique, "in a strong stranglehold of Eastern infiltrators", Schwarb judged Ciba-Geigy to be in a good position, as many competitors had reduced their activities. Despite the country's lack of foreign currency, Ciba-Geigy's products were of national interest and likely to be prioritised in the allocation of currency. ${ }^{66} \mathrm{~A}$ second journey to the two former colonies in early 1977 convinced Schwarb of Ciba-Geigy's favourable prospects, particularly in Mozambique. As this state's economy was based on agriculture, there would always be a need for agrochemical products, no matter how the political situation developed. He concluded that decolonisation had had a positive impact on the group's business: "Remaining foreigners confirm that the business of those firms whose structures are intact is not going worse, but rather better than before independence." ${ }^{n 7}$

64 R. Pargätzi, minutes no 9/75 of the Regional Services meeting on 21 November 1975, p. 4, Novartis archives, Ciba-Geigy company archives, Regional Services, minutes, box RD 1, 14/72-9/77; R. Pargätzi, minutes no 5/76 of the Regional Services meeting on 14 May 1976, p. 11, ibid.

65 Emphasis in original. H. Schwarb, report to the Executive Committee, "Bericht über meinen Aufenthalt in Luanda / Angola vom 16.-22.9.76”, o6.10.1976, p. 4, Novartis archives, CibaGeigy company archives, minutes: various documents, box KL 1.01, Aug 1976 - Dez 1979.

66 H. Schwarb, report to the Executive Committee, "Bericht über meinen Aufenthalt in Maputo, Mosambik vom 23-28.9.76", o7.10.1976, citation p. 1, Novartis archives, Ciba-Geigy company archives, minutes: various documents, box KL 1.01, Aug 1976 - Dez 1979; see also R. Pargätzi, minutes no $11 / 76$ of the Regional Services meeting on 22 October 1976, p. 5, Novartis archives, Ciba-Geigy company archives, Regional Services, minutes, box RD 1, 14/72-9/77.

67 H. Schwarb, report, "Bericht über meinen Aufenthalt in Angola / Mosambik vom 1.-10.3.77", 15.03.1977, p. 6, Novartis archives, Ciba-Geigy company archives, minutes: various documents, box KL 1.O1, Aug 1976 - Dez 1979. 
Ciba-Geigy's export figures for Mozambique between 1977 and 1979 back his assumption. Although they were subject to irregularities (1977: CHF 14.3 million, 1978: CH F 22.3 million, 1979: CHF 6.8 million), exports to Mozambique were significantly higher than in $1974{ }^{68}$ In 1980 , Ciba-Geigy achieved peak annual sales of more than CHF 20 million in both Angola and Mozambique. According to regional services in Basel, stability of staffing, both with regard to headquarters and expatriates working in Africa, was a prerequisite of success in these instable markets, as frequent personnel changes unsettled clients and local staff and hampered success. ${ }^{69}$

On the whole, Ciba-Geigy weathered the political and economic transformations in Mozambique during the late 1970s rather well. The group had the necessary financial backing to tide it over in the difficult years of 1975 and 1976. The strategic choice to maintain a minimal presence by keeping the Maputo branch office open paid off, as the group was later able to rely on a functioning infrastructure and established contact with clients to promote its sales. As chemicals and pharmaceuticals were of national interest, demand for CibaGeigy's products continued in spite of the great economic difficulties of independent Mozambique. Despite increasing competition from the Eastern bloc, the same was true for other well-established and well-known big Swiss export firms, mostly in the machine sector. The increasing administrative burdens they faced when dealing with state-controlled importers might even have been an advantage, as they eliminated less well-connected competitors.

In 1975, the Swiss government set greater store in developing bilateral relations than its Mozambican counterpart. Four years later, the situation was reversed. The FRELIMO administration undertook efforts to deepen bilateral relations that culminated in the conclusion of a bilateral Trade and Economic Cooperation Agreement in October 1979. In late January 1979, the Mozambican Foreign Minister, Joaquim Chissano, informed the Swiss embassy in Maputo that President Samora Machel wished to make a courtesy visit to Switzerland during a trip to Europe in the first half of the year. ${ }^{70}$ Maputo's diplomatic community explained that the choice of Switzerland, certainly not one of FRELIMo's sup-

68 No author, “Umsatzübersicht für ZIмвавWE und umliegende Länder", 12.09.1980, p. 1, attached to the minutes of the Regional Committee for Sub-Saharan Africa on 10 September 1980, 12.09.1980, Novartis archives, Ciba-Geigy company archives, regional management, minutes of the regional committees, box RD 7-8, Afrika: RD 7.2.

69 R. Pargätzi, minutes no 12/80 of the Regional Services meeting on 12 December 198o, p. 7, Novartis archives, Ciba-Geigy company archives, Regional Services, minutes, box RD 1, 10/77-12/80. Präsidenten der Volksrepublik Mosambik”, 24.01.1979, SFA E2200.307A\#1991/285\#24*. 
porters during the independence war, was due to the Mozambican authorities' wish to increase economic and especially financial cooperation. ${ }^{71}$ Three months after this initial contact, the FRELIMO government suddenly insisted on the official character of the visit with the corresponding protocol for 45 delegates. To Bern's further consternation, the Swiss chargé d'affaires in Maputo, ClaudeLouis Piachaud, heard on 5 May, ten days before Machel's scheduled arrival in Switzerland, that the Mozambican government had ambitious goals for the visit. It not only wished to deepen relations with Swiss firms and banks and to convince the Swiss government to grant ERG covers for deliveries to Mozambique but also wanted to sign bilateral treaties on economic, technical, and scientific cooperation. ${ }^{72}$ In Bern, this came as a surprise. The sTC had only just launched an aid programme for Mozambique a few months previously and had no intention of concluding a bilateral framework accord. ${ }^{73}$ During a preparatory meeting in Bern on 9 May 1979, FPD officials and a Mozambican delegation headed by Sergio Vieira, the Governor of the Mozambican national bank, failed to reach an agreement on the publication of a joint communiqué. Vieira therefore cancelled, or in his words, postponed, his head of state's visit. Nevertheless, the talks remained cordial and the Swiss authorities promised to study the drafts of a trade agreement and a general agreement of cooperation presented by Vieira. ${ }^{74}$

The Mozambican delegation's understanding attitude led Swiss diplomats in Maputo and Addis Ababa to suspect that FRELImo had abandoned the plans for Machel's trip beforehand. Two other scheduled visits had already been cancelled by May and internal difficulties rendered the absence of the head of state difficult. ${ }^{75}$ If they, indeed, engineered a last-minute cancellation in order to put pressure on the Swiss government to increase economic col-

71 Letter from Claude-Louis Piachaud to the Political Secretariat, "Voyage du Président Samora Machel en Suisse", 10.05.1979, very urgent and confidential, SFA E2200.307A\#1991/285\#24*; letter from John F. Doble, UK embassy in Mozambique, to K.J. Baudains, FCO, confidential, "Visits by Machel", 11.06.1979, TNA FCO 106/83.

Telegram no 19 from Claude-Louis Piachaud to the FPD, 05.05.1979, SFA E2200.307A\#1991/ $285^{\# 24}$; note from Hansjakob Kaufmann, head of the FPD's Protocol Service, to Federal Councillor Pierre Aubert, "Séance du Conseil federal du 2 mai 1979, 'Aussprache", 01.05.1979, SFA E2001E-o1\#1991/17_Bd. 984, B.15.50.4; letter from Piachaud to the Political Secretariat, "Voyage du Président Samora Machel en Suisse", 10.05.1979, very urgent and confidential, SFA E2200.307A\#1991/285\#24*.

73 Philippe de Rham, stc, memorandum, "Coopération au développement du Mozambique”, 03.05.1979, p. 4, SFA E2025A\#1991/168\#1259*.

74 Alfred Rüegg, DPA, memorandum, "Besuch Samora Machels", 11.05.1979, SFA E2001E -o1\#1991/17_Bd. 985, B.73.Moz.o.

75 Letter from Claude-Louis Piachaud to Fritz Bohnert, 17.05.1979, confidential, SFA E2200 .70\#1993/403\#3*; letter from Bohnert to the DPA, "Besuchsreise des mosambikanischen Präsidenten: ein Rückblick und ein Ausblick”, 29.10.1979, SFA E2200.307A\#1991/285\#24*. 
laboration, the Mozambican authorities certainly played their Swiss counterparts well. The national and international press explained the cancellation by citing Bern's unwillingness to receive more than one visit of state per year. This provoked a parliamentary question and aroused indignation in Swiss religious and Third World circles, which interpreted it as a sign of Bern's lack of respect towards the head of a Third World state. ${ }^{76}$

Thanks to the controversies surrounding Machel's cancelled visit to Bern, Switzerland's political and economic elites reacted quickly and favourably to the Mozambican wish to conclude economic agreements. Three weeks after the cancelled visits, the Swiss trade authorities had incorporated the two Mozambican draft agreements into a single Swiss counterproposal that was submitted to FRELIMO. Negotiations were speedy and constructive. On 22 October 1979, the two governments signed the Swiss-Mozambican Trade and Economic Cooperation Agreement. It covered the intensification of trade, the granting of most-favoured nation treatment, the protection of intellectual property, and the encouragement of cooperation in the economic, industrial, technical, agricultural, tourist, services, and healthcare sectors. As Switzerland's trade with and investments in Mozambique were limited, the Swiss government's willingness to negotiate an agreement with FRELIMO is explained by political motives. Most importantly, Bern hoped that the conclusion of a cooperation agreement would prove that bilateral relations between the two states were cordial and thereby calm critical voices in Switzerland. From a more long-term perspective, in early October, shortly before the signature of the agreement, the FDEA argued that Switzerland had a political interest in increasing its contact with the Southern African state bordering South Africa and Zimbabwe Rhodesia, and that the Mozambican government's wish to diversify its foreign economic relations should be encouraged. ${ }^{77}$

While the Mozambican government hesitated to establish diplomatic relations with Switzerland in 1975, humanitarian and development aid played a

76 "Question ordinaire Grobet du 21 juin (79.727). Abgesagter Besuch des Präsidenten von Mosambik. Visite annullée du Président du Mozambique", Amtliches Bulletin der Bundesversammlung 1979, Herbstsession Nationalrat, 05.10.1979, p. 1379; BJ, "Visite du Président de la République Populaire du Mozambique, M. Samora Machel - Succession des faits", o8.10.1979, SFA E2001E-o1\#1991/17_Bd. 984, B.15.50.4.

77 Letter from Ernst Henri Léchot to the Vorort, 28.05.1979, SFA E2001E-o1\#1991/17_Bd. 984, C.41.Moz.111.o; Jean-Jacques Maeder, Trade Division, to Paul Jolles, head of the Trade Division, "Handelsabkommen mit Mozambik", 29.10.1979, p. 2, SFA E7115A\#199o/6o\#1529*; proposal from the FDAE to the Federal Council, "Mozambik - Abkommen über Handel und wirtschaftliche Zusammenarbeit", o3.10.1979, attached to the decree of the Federal Council, "Mozambik - Abkommen über Handel und wirtschaftliche Zusammenarbeit, Fortsetzung von Verhandlungen", 24.10.1979, SFA E1004.1\#1000/9\#872*. 
crucial role in the normalisation of bilateral relations between the two states in the late 1970s. Aid calmed FRELIMo's criticism of Swiss foreign policy in sub-Saharan Africa. In the words of an STC officer, it "was used to buy the Swiss authorities a good conscience". ${ }^{78}$ Switzerland's development cooperation programme for Mozambique convinced the latter's government of Bern's willingness to engage in a long-term commitment to the Southern African state. At the same time, the strength of Switzerland's economy and the activities of well-known Swiss export companies and banks in Mozambique probably raised FRELIMO's hopes of benefiting from growing economic cooperation and motivated its push for the conclusion of bilateral trade and cooperation agreements. Mozambique's growing economic difficulties and the escalating conflict between FRELIMO and RENAMO in the 1980s dashed these hopes.

78 Letter from Philippe de Rham to Jean-Maurice Délèze, "'Pneumatologie mozambicaine”, o6.o6.1979, p. 3, SFA E2O25A\#1991/168\#1259*. 